\title{
Distribution changes after settlement in six species of damselfish (Pomacentridae) in One Tree Island lagoon, Great Barrier Reef
}

\author{
David J. Booth* \\ Department of Environmental Sciences, University of Technology, Sydney, Westbourne Street, Gore Hill NSW 2065, Australia
}

\begin{abstract}
While larval supply patterns play a major role in determining the distribution and abundance of reef fishes at a range of spatial and temporal scales, events occurring in the weeks after settlement may also significantly alter the demography of a juvenile population. I monitored over 2 summers the arrival of new recruits of 6 species of benthic damselfish onto continuous and patch reef habitat in One Tree Island lagoon. Each species had specific habitat preferences, and most showed some form of patchiness in spatial and temporal distribution at settlement; however, this was most likely a result of group settlement rather than habitat patchiness. Tagged recruits of Pomacentrus amboinensis remained within $1 \mathrm{~m}$ of their settlement site for at least the first $36 \mathrm{~d}$ on continuous reef, while known individuals of other species also moved little during this period, suggesting that disappearances were likely to be due to mortality. Mortality of recruits varied among species, years and habitats (patch vs continuous reef), and consequently spatial distributions of fish changed after settlement at the scale of 10 s of metres (within-site) and several kilometres (among 8 sites). The spatial patchiness in distributions was not consistent among species, sites or years, suggesting that spatial variation in substrate did not have a major effect on settlement variation at this scale. These results show that the settlement signal may be obscured in the first few weeks post-settlement, and that lessfrequent censuses, commonly used as proxies for high-frequency monitoring of settlement, may not accurately hindcast spatial or temporal patterns of settlement.
\end{abstract}

KEY WORDS: Damselfishes · Group settlement - Migration · One Tree lagoon · Post-settlement mortality

Resale or republication not permitted without written consent of the publisher

\section{INTRODUCTION}

While most marine species have a life cycle that incorporates a pelagic larval stage and benthic or demersal juveniles and adults, little is known of the pelagic phase or processes that occur as individuals arrive at adult habitat. Some evidence that these stages can have strong influences on the demography of adults has been gathered, providing support for a recruitment-limitation hypothesis for reef fishes (e.g. Williams 1980, Doherty 1983) and other organisms

\footnotetext{
*E-mail: david.booth@uts.edu.au
}

(Roughgarden et al. 1988). Despite this, in many models of dispersal, larvae are treated as passive particles, leading to the prediction that dispersal follows ocean current patterns (e.g. Roberts 1997). However, more recently it has been demonstrated that larvae have strong behavioural and physiological abilities to orient independent of currents (Leis \& Carson-Ewart 1999). In other marine organisms, swimming behaviour can determine vertical zonation on rocky shores (ascidians: Grosberg 1982), and the duration of the settling-search phase can influence spatial distribution of recruits (Davis \& Butler 1989).

In coral reef fishes, presettlement fish are known to have considerable swimming abilities (e.g. Stobutski \& 
Bellwood 1997), and show preferences for certain swimming directions around reefs (e.g. Leis \& CarsonEwart 1999). Once they arrive in the vicinity of a reef, larvae may detect the reef's lagoonal waters and avoid entry (e.g. Doherty et al. 1996). Close to the reef, larvae may prefer certain habitats, and may be attracted to or actively avoid conspecifics (e.g. Sweatman 1985, Booth 1992). Holbrook et al. (2000) demonstrated that habitat distribution, not larval supply, accounted for spatial variation in distribution of newly settled damselfish Dascyllus aruanus among widely spaced reefs in French Polynesia, while Srinivasan et al. (1999) showed similar control of distribution by habitat for species of anemonefish Amphiprion spp. These taxa are known to have very specific habitat preferences, and it is not surprising that habitat largely controls distribution. However, other reef fish species may be less dependent on specific habitat type, and less is known of how well settlement predicts subsequent post-settlement distribution in these species (e.g. Lewis 1997).

Settlement behaviour has the potential to alter the distribution of new settlers, and subsequently older fish at a number of spatial and temporal scales (e.g. Booth \& Wellington 1998). However, little direct evidence of such effects of settlement behaviour is available. Breitburg (1991) showed that nearshore aggregations of naked gobies on temperate oyster reefs influenced settlement distribution, while Sweatman (1985) and Booth (1995) demonstrated that settling Dascyllus spp. selectively chose coral heads already supporting conspecifics. Ohman et al. (1998) recorded species-specific habitat choices for late-stage larval

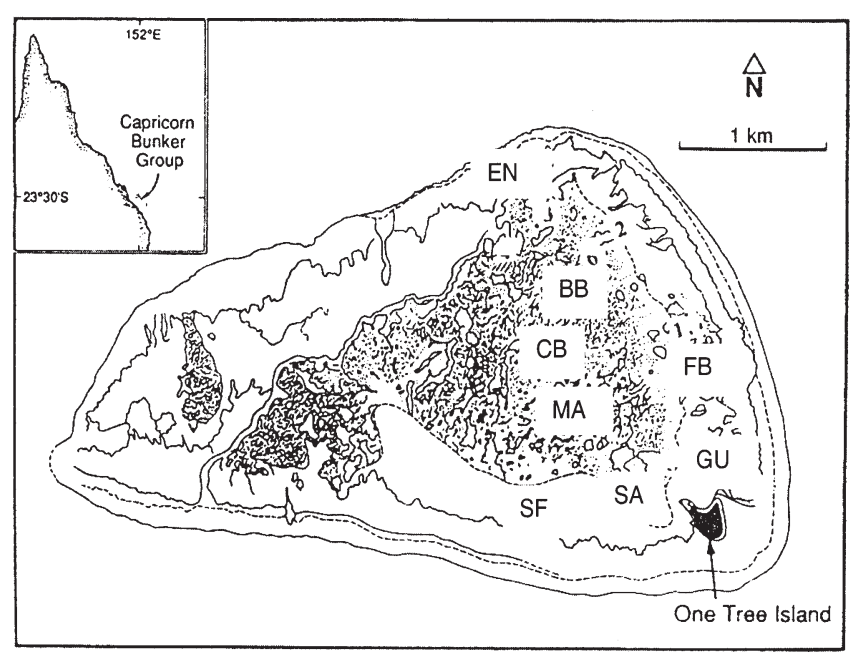

Fig. 1. Aerial map of One Tree Island (dark) and One Tree lagoon, showing locations of 8 sites within the first lagoon. $\mathrm{SA}=$ Shark Alley, $\mathrm{GU}=$ Gutter, $\mathrm{EN}=$ Entrance, $\mathrm{SF}=$ Sandflat, $\mathrm{FB}=$ First Bank, $\mathrm{CB}=$ Centre Bommie, $\mathrm{MA}=$ Maze, $\mathrm{BB}=\mathrm{Big}$ Bommies damselfishes, either preferring or avoiding particular habitat types or conspecifics.

Habitat hotspots for settlement at larger spatial scales have been identified for coral reef fishes, due to patchiness of high-quality habitat (Munday et al. 1997), oceanographic features such as currents that direct larvae to certain locations (e.g. Sponaugle \& Cowen 1997) or combinations of habitat and oceanographic features (e.g. Booth et al. 2000). It is important to identify such hotspots, as they may indicate patchiness of post-settlement predation or settlement preferences for resources, and be useful identifying management options such as habitat enhancement.

Understanding the demographic effects of early post-settlement processes of predation and migration is also important in justifying the use of late season recruitment surveys as proxies for more frequent censuses in determination of larval supply to a reef (e.g. Williams et al. 1994). These assume that settlement patterns are not modified between settlement and endof-season censuses, but if mortality and/or migration are variable in space and time (e.g. Levin 1998), they will obscure settlement patterns.

In this study, the change in distribution of 6 species of damselfishes (Pomacentridae) over about 6 mo postsettlement at a small spatial scale, and between $2 \mathrm{yr}$, is interpreted in the light of possible migration and mortality. Specifically, the study asks: (1) Are hotspots for settlement temporally persistent? (2) Do spatial patterns of settlement suggest either habitat associations or group settlement? (3) Is persistence in the weeks post-settlement variable spatially and temporally, and among species? And (4) as a consequence, are patterns of distribution established at settlement obscured over the first months post-settlement, and therefore are censuses made at the end of the settlement season (sensu Williams et al. 1994) indicative of actual settlement patterns?

\section{MATERIALS AND METHODS}

Study site and species. One Tree Island lagoon is located at the southern end of the Great Barrier Reef, in the Bunker Group ( $\left.23^{\circ} 30^{\prime} \mathrm{S}, 152^{\circ} 06^{\prime} \mathrm{E}\right)$. The lagoon contains a convoluted series of continuous reef zones, or piecrust, extending from the surface to depths of from 1 to $4 \mathrm{~m}$. Between piecrust areas, deeper patch reefs ( 2 to $7 \mathrm{~m}$ below the surface) are surrounded by sand. This study was carried out on piecrust and constructed patch reefs in Shark Alley, on the southeastern side of the lagoon, and at 7 other sites in the lagoon (Fig. 1). Shark Alley is the site of highest settlement of damselfishes (Pomacentridae) within the lagoon, which settle in both patch reef and piecrust habitats (Booth et al. 2000). 
Spatial and temporal distribution of fish. Visual surveys were carried out for settler, recruit, juvenile and adult damselfishes on piecrust transects at 8 sites and 6 artificial patch reefs in Shark Alley. Transects comprised two $75 \mathrm{~m}$ stretches of continuous reef at each site and were marked off into $1 \mathrm{~m}$ portions using flagging tape and underwater buoys. The observer slowly swam along the transect, which varied from 1 to $2.5 \mathrm{~m}$ in width, depending on piecrust depth and topography, and noted the identity and location (to the nearest metre) of each pomacentrid. Fish were categorised as settler $(<15 \mathrm{~mm}$ TL with reduced caudal pigmentation and of similar length to pre-settlement fish caught adjacent to the reefs by light traps, unpubl. data), recruit (15 to $25 \mathrm{~mm} \mathrm{TL}$ ), juvenile ( 25 to $40 \mathrm{~mm} \mathrm{TL}$ ) or adult ( $>40 \mathrm{~mm} \mathrm{TL}$, or with adult pigmentation). All length estimates were verified by capturing fish throughout the study, with less than $5 \%$ of estimates leading to incorrect classification (unpubl. data).

In Shark Alley, 6 patch reefs were constructed of dead coral rubble, and situated in 3 to $5 \mathrm{~m}$ of water, approximately $15 \mathrm{~m}$ off the piecrust reef on sand and separated by at least $10 \mathrm{~m}$ from other hard substrate. Each patch reef was approximately $1 \times 1 \times 0.5 \mathrm{~m}$ high. They were surveyed by slowly approaching and counting fish as for transect surveys.

Surveys of both transects and patch reefs were conducted around new moon periods, every 1 to $3 \mathrm{~d}$, from November 24 to December 8, 1993, December 26, 1993 to January 6, 1994, January 20 to February 21, 1994, November 28 to December 13, 1994, December 26, 1994 to January 8, 1995 and January 23 to February 8, 1995. In total, 26 censuses were conducted over $57 \mathrm{~d}$ in 1993/1994, and 17 censuses over 44 d in 1994/1995, with approximately similar mean census intervals between years. Outside these periods, settlement rates were low, although a pulse of Pomacentrus nagasakiensis settlement occurred in March 1994 (unpubl. data). In addition, single censuses were conducted for recruits at all sites in late February, and for juveniles in April 1994 and 1995.

Spatial distribution of fish in Shark Alley from settlement over the summer through to April in 1993/1994 was compared using correlation analysis between settler distribution (number of settlers in each of 150, $1 \mathrm{~m}$ segments of transect) and recruits, juveniles or adults. Patterns of aggregation of settlers were tested using the coefficient of dispersion (Sokal \& Rohlf 1995).

Settler and recruit persistence. Locations of known individuals were recorded during each census. Some fish were recognised by unusual pigmentation, while others were rare, and it was assumed that fish of similar size and location on successive censuses were identical. Individuals of 1 species (Pomacentrus amboinensis, $\mathrm{n}=28$ ) were tagged with a subcutaneous injection of tattoo ink and observed during subsequent censuses, including intensive searches of adjacent areas up to $20 \mathrm{~m}$ away from transects. Therefore, migration over the scale of several metres could be estimated, and it was assumed that disappearance of these individuals was tantamount to mortality. Recruit persistence was estimated as the ratio of juveniles remaining of each species in April to recruits censused in the previous February, while settler persistence was the ratio of juveniles to settlers.

Microhabitat monitoring. Every $5 \mathrm{~m}$ along transects in Shark Alley, microhabitat was monitored by placing a $1 \mathrm{~m}^{2}$ quadrat midway between the upper and lower boundary of the transect. The percentage cover of several broad habitat categories was estimated within the quadrat. Broad categories used were: dead coral, branching corals (mainly Porites sp., Stylophora sp., Pocillopora damicornis) and conspecific density. Multiple regression analysis (Zar 1996) was used to model the relationship between numbers of settlers in $\mathrm{m}$ segments of the transect $(n=24)$ with corresponding habitat values.

\section{RESULTS}

\section{Patterns of settlement}

A total of 13 species of pomacentrid settled on transects in Shark Alley during the study, of which 6 were common (Table 1). Of these, settlers were found in distinct species-specific microhabitats. Pomacentrus moluccensis were usually located in small branching coral heads (Acropora spp., Stylophora sp.), often with

Table 1. Settlement of pomacentrids at Shark Alley, One Tree Island, based on censuses every 1 to $3 \mathrm{~d}$ (Pie: $150 \mathrm{~m}$ of continuous reef; Patch: 6 small patch reefs)

\begin{tabular}{|lrrrr|}
\hline \multirow{2}{*}{ Species } & \multicolumn{3}{c}{$1993 / 1995$} & \multicolumn{2}{c|}{$1994 / 1995$} \\
& Pie & Patch & Pie & Patch \\
\hline Chromis nitida & 0 & 8 & 0 & 4 \\
Chromis cyanea & 0 & 0 & 1 & 0 \\
Chrysiptera rollandi & 235 & 0 & 56 & 0 \\
Dischistodus perspicillatus & 112 & 3 & 9 & 2 \\
Dischistodus sp. & 10 & 0 & 8 & 0 \\
Neoglyphidodon melas & 3 & 0 & 2 & 0 \\
Pomacentrus amboinensis & 11 & 24 & 2 & 8 \\
Pomacentrus bankanensis & 2 & 0 & 0 & 0 \\
Pomacentrus coelestis & 1 & 0 & 0 & 1 \\
Pomacentrus flavicauda & 2 & 0 & 0 & 0 \\
Pomacentrus moluccensis & 247 & 0 & 19 & 0 \\
Pomacentrus nagasakiensis & 0 & 20 & 0 & 2 \\
Pomacentrus wardi & 41 & 0 & 20 & 0 \\
Unidentified pomacentrids & 2 & 0 & 0 & 0 \\
Total & 666 & 55 & 117 & 17 \\
\hline
\end{tabular}




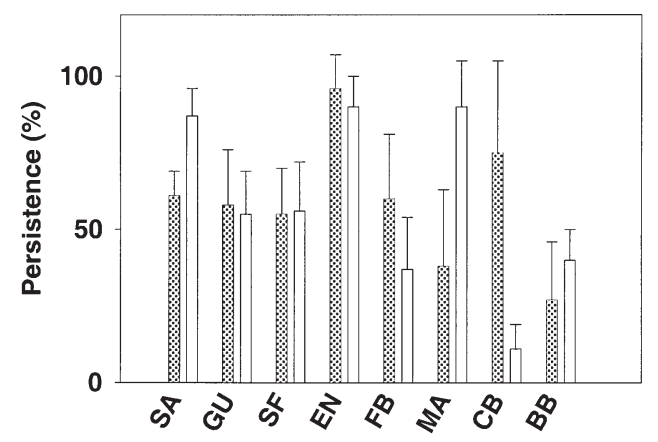

Fig. 2. Persistence (percentage remaining) of recruit Pomacentrus moluccensis (shaded bars) and Chrysiptera rollandi (blank bars) from February to April 1994 on continuous reef at 8 sites in One Tree Island lagoon. Mean \pm SE $(n=6$ transects per site. Original number of recruits per site: Shark Alley (Pomacentrus moluccensis: 247; Chrysiptera rollandi: 134); Gutter (46, 48); Sandflats $(44,64)$; Entrance $(53,26)$; First Bank $(13,42)$; Maze $(16,16)$; Centre Bommie $(8,17)$; and Big Bommies $(18,10)$. For an explanation of the abbreviations of site locations see Fig. 1

groups of conspecifics. P. wardi, Dischistodus perspicillatus and Chrysiptera rollandi settle on piecrust rubble, although the latter is restricted to the base of the reef, adjacent to sand. $P$. nagasakiensis settled almost exclusively on the patch reefs, while $P$. amboinensis settled on both habitats, although more commonly on patch reefs (Table 1). Settlement of all species was much lower in the second summer (1994/1995), especially $D$. perspicillatus (10\% of 1993/1994 settlement) and $P$. moluccensis (8 \% of 1993/1994 settlement). Most settlement occurred from mid-December to early February in both years, although a large pulse of settlement of $P$. nagasakiensis occurred on patch reefs sometime between late February and April in 1994.

\section{Persistence, migration and mortality}

Observations of the fate of individual settlers over successive censuses suggested that movement was minimal $(<1 \mathrm{~m})$, in no case $>2 \mathrm{~m}$. Pomacentrus amboinensis was the only species common on both patch reef and piecrust habitat. On January 15, 1995, 28 recruits (Mean $\pm \mathrm{SE}, 16.2 \pm 0.3 \mathrm{~mm}$ Total length) were marked, and recaptured on February 21. Only 3 fish disappeared over this period (1 from piecrust, 2 from patch reefs), 1 of which did not recover fully from marking, suggesting mortality was low in both habitats. After $36 \mathrm{~d}$, no marked fish had moved between patch reefs, and piecrust fish had moved only $1.0 \pm$ $0.2 \mathrm{~m}$ from their settlement sites $(\mathrm{n}=10)$, suggesting that migration during this period was minimal in both habitats.

Settler persistence, the ratio of juveniles to settlers, varied both among species and between years (Table 2). Pomacentrus moluccensis settler persistence differed from $26 \%$ in $1993 / 1994$ to $85 \%$ in $1994 / 1995$. The other 2 species for which estimates could be made in both years, Chrysiptera rollandi and P. wardi, had similar persistence between years. $P$. amboinensis settler persistence was similar in both continuous and patch reef habitat. Overall, settler persistence ranged from 20 to $37 \%$ among species and years in Shark Alley, except for P. moluccensis in 1994/1995. Recruit persistence (from recruitment [late February] to April in 1994) differed among 8 sites, for P. moluccensis and C. rollandi (Fig. 2). Persistence was low (40 to $50 \%$ ) for both species at the First Bank and Big Bommies sites, high for both species at the Entrance site (90 to 95\%), but was lower for $P$. moluccensis (35 to $60 \%$ ) than $C$. rollandi (85 to $90 \%$ ) at Shark Alley and the Maze site. In addition, variation in persistence among transects at

Table 2. Pearson correlations between settlement and recruit, juvenile and adult distribution along a $150 \mathrm{~m}$ transect at Shark Alley, One Tree Island lagoon (for Pomacentrus moluccensis, Dischistodus perspicillatus, $P$. wardi, Chrysiptera rollandi and P. amboinensis) and among 6 patch reefs (for $P$. amboinensis and $P$. nagasakiensis), ${ }^{*} 0.01<\mathrm{p}<0.05,{ }^{* *} \mathrm{p}<0.01$, otherwise not significant, $\mathrm{n}=150 \mathrm{~m}$ sections for piecrust, $\mathrm{n}=6$ for patch reefs. Bold: 1993/1994, roman: 1994/1995, $\mathrm{n} / \mathrm{a}$ : low sample sizes precluded statistical analysis. Settler persistence is the percentage of settlers remaining as juveniles in the subsequent April census

\begin{tabular}{|c|c|c|c|c|c|c|c|}
\hline Relationship & $\begin{array}{c}\text { Pomacentrus } \\
\text { moluccensis }\end{array}$ & $\begin{array}{l}\text { Dischistodus } \\
\text { perspicillatus }\end{array}$ & $\begin{array}{c}P . \\
\text { wardi }\end{array}$ & $\begin{array}{l}\text { Chrysiptera } \\
\text { rollandi }\end{array}$ & $\begin{array}{c}P . \\
\text { amboinen- } \\
\text { sis pie }\end{array}$ & $\begin{array}{c}P . \\
\text { amboinen- } \\
\text { sis patch }\end{array}$ & $\begin{array}{c}P . \\
\text { nagasaki- } \\
\text { ensis patch }\end{array}$ \\
\hline \multirow[t]{2}{*}{ Settlement vs recruitment } & $0.506^{* *}$ & 0.133 & $0.253^{* *}$ & $0.590^{* *}$ & 0.040 & 0.07 & $0.95^{* *}$ \\
\hline & $0.278^{* *}$ & $\mathrm{n} / \mathrm{a}$ & $0.393^{* *}$ & $0.449^{* *}$ & $\mathrm{n} / \mathrm{a}$ & $\mathrm{n} / \mathrm{a}$ & $\mathrm{n} / \mathrm{a}$ \\
\hline \multirow[t]{2}{*}{ Settlers vs juveniles } & 0.106 & 0.066 & 0.058 & 0.125 & 0.045 & -0.15 & 0.186 \\
\hline & $0.368^{* *}$ & $\mathrm{n} / \mathrm{a}$ & 0.067 & 0.070 & $\mathrm{n} / \mathrm{a}$ & $\mathrm{n} / \mathrm{a}$ & $\mathrm{n} / \mathrm{a}$ \\
\hline \multirow[t]{2}{*}{ Settlers vs adults } & -0.02 & -0.02 & 0.077 & 0.033 & $\mathbf{n} / \mathbf{a}$ & $\mathbf{n} / \mathbf{a}$ & $\mathbf{n} / \mathbf{a}$ \\
\hline & 0.173 & $\mathrm{n} / \mathrm{a}$ & 0.024 & 0.117 & $\mathrm{n} / \mathrm{a}$ & $\mathrm{n} / \mathrm{a}$ & $\mathrm{n} / \mathrm{a}$ \\
\hline \multirow[t]{2}{*}{ Settler persistence } & $26 \%$ & $23 \%$ & $26 \%$ & $31.5 \%$ & $33 \%$ & $37 \%$ & n/a \\
\hline & $85 \%$ & $\mathrm{n} / \mathrm{a}$ & $20 \%$ & $34 \%$ & $\mathrm{n} / \mathrm{a}$ & $\mathrm{n} / \mathrm{a}$ & $\mathbf{n} / \mathbf{a}$ \\
\hline $\begin{array}{l}\text { Settlement distribution } \\
\text { between years }\end{array}$ & 0.098 & $\mathbf{n} / \mathbf{a}$ & 0.058 & 0.101 & n/a & $\mathbf{n} / \mathbf{a}$ & $\mathbf{n} / \mathbf{a}$ \\
\hline
\end{tabular}



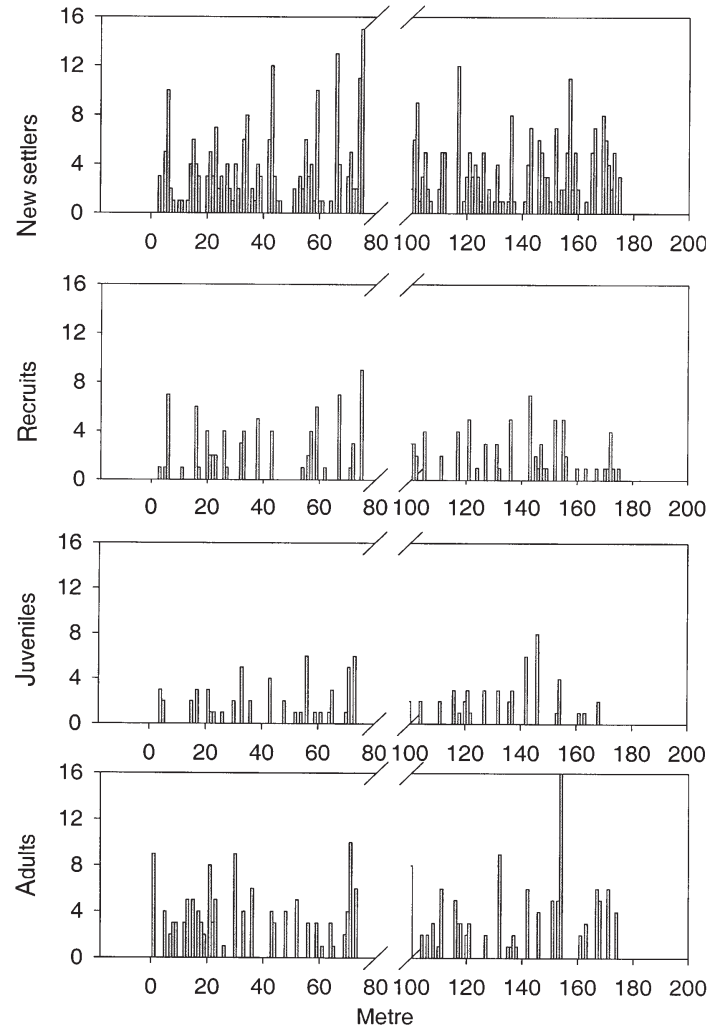

Fig. 3. Settlement, recruitment, juvenile and adult densities of Pomacentrus moluccensis along $150 \mathrm{~m}$ of continuous reef in One Tree Island lagoon, GBR. Settlement from November 1993 to February 1994, Recruitment late February 1994, juveniles April 1994, adults censused in February 1994

all sites (seen as high SEs in Fig. 2) indicates a change in the distribution of recruits among transects between February and April. In some transects, such as for $C$. rollandi at the Maze site, more juveniles were present in April than recruits censused in the previous February (SEs extending $>100 \%$ in Fig. 2), indicating either underestimates of recruit numbers in February, settlement subsequent to the February census, or emigration from adjacent habitat.

\section{Post-settlement changes in spatial distribution of settlers}

In general, spatial patterns of recruits within the Shark Alley site in late February each season reflected those at settlement (high correlation) for 4 of the 6 species investigated (Table 2, Fig. 3). The strength of the spatial relationship between settlers and recruits, however, differed between years. For Dischistodus perspicillatus on piecrust and Pomacentrus nagasakiensis on patch reefs, the settlement signal was lost by the late
February recruitment census. In the latter species for instance, all settlers disappeared from 1 of the 6 patch reefs ( $\mathrm{n}=7$ settlers) before the recruitment census, possibly due to a predation event.

For all species in both years (except Pomacentrus moluccensis in 1994/1995), patterns of juvenile distribution in Shark Alley did not reflect settlement patterns, and were not related to spatial distribution of adults (Table 2, Fig. 3).

\section{Interannual changes in spatial distribution of settlers: evidence for habitat hotspots?}

If habitat hotspots within the Shark Alley site existed, a high degree of correlation between spatial distribution of settlers in successive years would be expected. For the 3 most common species censused on continuous reef in both years (Pomacentrus moluccensis, P. wardi and Chrysiptera rollandi), there were no such significant correlations (Table 2, Fig. 4), suggesting that attributes of the habitat at this scale are not responsible for any clumping of settlement. The choice of $1 \mathrm{~m}$ segments of transect for these analyses was arbitrary, but reanalysis using 2 and $5 \mathrm{~m}$ segments also did not detect significant correlations between years (unpubl. data).

In addition, multiple regression analysis did not reveal any associations of setters with broad habitat categories. A model containing percent cover of dead coral, live branching corals and number of conspecifics failed to predict spatial variation in settlement along the Shark Alley transects in 1993/1994 (Multiple regression models: Pomacentrus moluccensis, $\mathrm{R}^{2}=$ $0.14, \mathrm{p}=0.82, \mathrm{n}=24 \mathrm{~m}$ sections; Chrysiptera rollandi, $\mathrm{R}^{2}=0.28, \mathrm{p}=0.40, \mathrm{n}=24$; Dischistodus perspicillatus, $\mathrm{R}^{2}=0.16, \mathrm{p}=0.78, \mathrm{n}=24$ ).

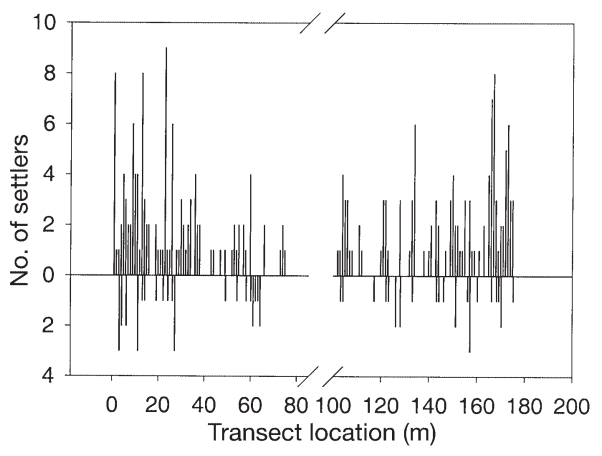

Fig. 4. Patterns of settlement of Chrysiptera rollandi across a $150 \mathrm{~m}$ transect of continuous reef in One Tree Island lagoon, December 1993 to February 1994 (upper, $\mathrm{n}=235$ settlers) and December 1994 to February 1995 (lower, n = 56 settlers) 


\section{Evidence for grouping at settlement}

When spatial patchiness of new settlers was tested on a daily basis, both of the 2 species that settled in sufficient numbers to perform statistical tests appeared to arrive on the reef in groups. Groups were defined as settlers of the same species arriving in a metre of transect on a given date. Pomacentrus moluccensis settlers arrived in groups of up to 12 individuals, and showed high coefficients of dispersion, indicating clumping (1.43 to 3.1, where 1 indicates random: Sokal \& Rohlf 1995). Chrysiptera rollandi arrived in groups of up to 5 individuals (coefficients of dispersion 1.1 to 1.8), also indicating group settlement.

For $60 \%$ of census days for Pomacentrus moluccensis, and $90 \%$ of census days for Chrysiptera rollandi, there was no spatial correlation between number of setters and number of resident conspecifics, including settlers, recruits, juveniles and adults (Pearson correlation coefficients, $p>0.05$ ), suggesting that clumped settlement was not normally an artefact of attraction to higher densities of conspecifics. Also, as above, spatial 'hotspots' of settlement were not apparent (Table 2), inferring that settlers likely arrived in discrete groups.

\section{DISCUSSION}

At the scale of 10 s of metres and several kilometres, over 2 successive years, pomacentrid settlement and persistence were highly variable. This differed among species. This patchiness was not related to habitat patchiness or, for the most part, conspecific distribution, and may have been at least partly a function of clumping of larvae just prior to settlement. Post-settlement variation in demographic processes therefore decoupled the link between larval supply and recruitment at this scale. The large variation in the fate of settlers among species and years also indicates that censuses of juveniles may be poor proxies for settlement in these species.

As demonstrated in other studies (e.g. Booth 1991), pomacentrid settlers do not appear to migrate away from the site of settlement in the first months. This suggests that disappearance of these fish from within transects is tantamount to mortality. Low rates of early post-settlement dispersal are characteristic of pomacentrids (Booth 1991, Ault \& Johnson 1998) and may help reduce predation risk (Beukers \& Jones 1998), although many other coral reef fish taxa have higher rates of migration between patches (Lewis 1997).

While species did associate with particular microhabitats at small spatial scales, the patchiness of microhabitat or conspecific density could not explain distributions of settlers along the transect, and 'hotspots' of high settler density varied between years. Such hotspots are therefore more likely to be the result of random arrival of groups of larvae. Such clumping may be passive (the result of advection processes such as local eddies: Kingsford et al. 1991), behavioural (e.g. Breitburg 1991, Munday et al. 1997), or an artefact of patchiness of predation (Hixon \& Carr 1997). Habitat hotspots at these small spatial scales have been shown to be important for some species (e.g. Tolimieri 1995), but in that study were not found to 'scale up' to help explain large-scale variation in recruitment. At wholereef scales in One Tree Island lagoon, Shark Alley has been shown to be a recruitment hotspot for pomacentrids for at least several decades (e.g. Williams 1980, Booth et al. 2000), and higher cover of live branching corals may be partly responsible for this (Booth et al. 2000). It is surprising, therefore, that patchiness of live corals was not a good predictor of patchiness in settlement of Pomacentrus moluccensus within Shark Alley, since it is known to settle preferentially on live branching corals (Mapstone 1988). Despite observations in the present study (unpubl. data) that $P$. moluccensis almost exclusively settled in live branching Pocillopora damicornis or Stylophora sp., this habitat was present in some quantity in all $1 \mathrm{~m}$ segments of transects and so may not have been limiting.

At the scale of the present study, the distributional patterns established at settlement were completely erased during the first months post-settlement, suggesting negatively density-dependent mortality, except for Pomacentrus moluccensis in 1994/1995 (Table 2). In addition, aggregation of settlers was not apparent in later stages (recruits, juveniles and adults), suggesting that either density-dependent predation (e.g. Hixon 1998) or behavioural interactions of settlers led to more regular or random spacing of individuals. In contrast, Connell (1997) found that patchiness of predation, likely to be the major source of mortality on settlers (e.g. Hixon \& Carr 1997), was not responsible for altering distribution patterns established at settlement for the spiny damselfish Acanthochromis polyacanthus at scales of 100s of metres in One Tree Island lagoon. Despite this, it is clear that knowledge of distribution of settlers may not predict juvenile and adult distributions on a reef at small spatial scales, and conversely that estimating settlement by censusing juveniles may be equally problematic. Levin (1998) demonstrated that post-settlement mortality can significantly modify initial settlement patterns of benthic reef fishes, while Steele (1997) found that early post-settlement processes obscured settlement patterns in Californian gobies. In his study, strong density dependence of mortality was also responsible for the loss of the settlement signal. Sponaugle \& Cowen (1996) showed that juvenile distribution of 1 species of Caribbean reef fish (the dam- 
selfish Stegastes partitus) closely reflected settlement patterns, while juveniles of the surgeonfish Acanthurus bahinus were most abundant at sites of lower settlement, which had more suitable habitat. The maintenance of distribution patterns for $P$. moluccensis in 1994/1995 compared to 1993/1994 was paralleled by an unusually high persistence in 1995 (85\% of settlers were present in April censuses). This suggests that predation pressure, for whatever reason, may have been unusually low on that species in that year, so that normal density-dependent mortality did not occur.

A common practice for estimating the strength of the annual settlement pulse for fish species on coral reefs is to conduct 1 census after the settlement period (e.g. in April on the Great Barrier Reef) as a proxy for frequent settlement censuses (see Williams et al. 1994). This protocol assumes that persistence of settlers through to April is not variable among years, sites and species. Robertson \& Kaufmann (1998) claim that such end-of-season surveys are not useful where settlement occurs in several pulses throughout the year, as for many Caribbean fishes. The present study has shown that end-of-year censuses may also be poor proxies of settlement for species with more contracted annual settlement, such as damselfishes in One Tree lagoon. The persistence of settlers through April of each year differed for each of the 3 species for which data were sufficient, and among sites and years. While end-ofseason censuses (sensu Williams et al. 1994) may not indicate settlement patterns as those authors claim, they may be useful indicators of future cohort strength once early post-settlement redistribution and patchy mortality has slowed. Despite frequent (1 to $3 \mathrm{~d}$ intervals) censuses used in this study, actual patterns of settlement may already have been obscured through patchy mortality or migration (e.g. Booth 1991). It is recommended that daily, or even twice-daily, censuses be used if actual settlement patterns are to be investigated.

Acknowledgements. I wish to thank the staff of One Tree Island Research Station for their co-operation and for use of facilities, and Drs P. Doherty and M. Kingsford for support. The study was funded through ARC grants to P.D. and M.K., and an ARC Postdoctoral Fellowship to D.J.B. Many thanks also to Gigi Beretta for her field assistance and advice and to 3 anonymous reviewers.

\section{LITERATURE CITED}

Ault TR, Johnson CR (1998) Relationships between habitat and recruitment of three species of damselfish (Pomacentridae) at Heron Reef, Great Barrier Reef. J Exp Mar Biol Ecol 223:145-166

Beukers JS, Jones GP (1998) Habitat complexity modifies the impact of piscivores on a coral reef fish population. Oecologia 114:50-59
Booth DJ (1991) The effects of sampling frequency on estimates of recruitment of the domino damselfish Dascyllus albisella. J Exp Mar Biol Ecol 145:149-159

Booth DJ (1992) Larval settlement patterns and preferences by domino damselfish Dascyllus albisella Gill. J Exp Mar Biol Ecol 155:85-104

Booth DJ (1995) Juvenile groups in a coral reef damselfish: density-dependent effects on individual fitness and population demography. Ecology 76:91-106

Booth DJ, Wellington G (1998) Settlement preferences in coral-reef fishes: effects on patterns of adult and juvenile distributions, individual fitness and population structure. Aust J Ecol 23:274-279

Booth DJ, Kingsford MJ, Doherty PJ, Beretta GA (2000) Recruitment of damselfishes in One Tree Island lagoon: persistent interannual spatial patterns. Mar Ecol Prog Ser 202:219-230

Breitburg DL (1991) Demersal schooling prior to settlement by larvae of the naked goby. Environ Biol Fishes 26: 97-103

Connell SD (1997) The relationship between large predatory fish and recruitment and mortality of juvenile coral reef fish on artificial reefs. J Exp Mar Biol Ecol 209:261-278

Davis AR, Butler AJ (1989) Direct observations of larval dispersal in the colonial ascidian Podoclavella moluccensis Sluiter: evidence for closed populations. J Exp Mar Biol Ecol 127:189-203

Doherty PJ (1983) Tropical territorial damselfishes: is density limited by aggression or recruitment? Ecology 64:176-190

Doherty PJ, Kingsford MJ, Booth DJ, Carelton J (1996) Habitat selection before settlement by Pomacentrus coelestis. Mar Freshw Res 47:391-400

Grosberg RK (1982) Competitive ability influences habitat choice in marine invertebrates. Nature 290:700-702

Hixon MA (1998) Population dynamics of coral-reef fishescontroversial concepts and hypotheses. Aust J Ecol 23: 192-201

Hixon MA, Carr MH (1997) Synergistic predation, density dependence, and population regulation in marine fish. Science 277:946-949

Holbrook SJ, Forrester GE, Schmitt RJ (2000) Spatial patterns in abundance of a damselfish reflect availability of suitable habitat. Oecologia 122:109-120

Jones GP (1997) Relationships between recruitment and postrecruitment processes in lagoonal populations of two coral reef fishes. J Exp Mar Biol Ecol 213:231-246

Kingsford MJ, Wolanski E, Choat JH (1991) Influence of tidally induced fronts and Langmuir circulations on distribution and movements of presettlement fishes around a coral reef. Mar Biol 109:167-180

Leis JM, Carson-Ewart BM (1999) In situ swimming and settlement behaviour of larvae of an Indo-Pacific coral-reef fish, the coral trout Plectropomus leopardus (Pisces: Serranidae). Mar Biol 134:51-64

Levin PS (1998) The significance of variable and density independent post-recruitment mortality in local populations of reef fishes. Aust J Ecol 23:246-251

Lewis AR (1997) Recruitment and post-recruit immigration affect the local population size of coral reef fishes. Coral Reefs 16:139-149

Mapstone BD (1988) The determination of patterns in the abundance of Pomacentrus moluccensis on the southern Great Barrier Reef. PhD thesis, University of Sydney

Munday PL, Jones GP, Caley MJ (1997) Habitat specialisation and the distribution and abundance if coral-dwelling gobies. Mar Ecol Prog Ser 152:227-239

Ohman MC, Munday PL, Jones GP, Caley MJ (1998) Settle- 
ment strategies and distribution patterns of coral-reef fishes. J Exp Mar Biol Ecol 225:219-238

Roberts CM (1997) Connectivity and management of Caribbean coral reefs. Science 278:1454-1457

Robertson DR, Kaufmann KC (1998) Assessing early recruitment dynamics and its demographic consequences among tropical reef fishes accommodating variation in recruitment seasonality and longevity. Aust J Ecol 23:226-233

Roughgarden J, Gaines S, Possingham H (1988) Recruitment dynamics in complex life cycles. Science 241:1460-1466

Sokal RR, Rohlf FJ (1995) Biometry. 3rd edn. Freeman, New York

Sponaugle S, Cowen RK (1996) Larval supply and patterns of recruitment for two Caribbean reef fishes, Stegastes partitus and Acanthurus bahinus. Mar Freshw Res 47:433-447

Sponaugle S, Cowen RK (1997) Early life-history traits and recruitment patterns of Caribbean wrasses. Ecol Monogr 67:177-202

Srinivasan M, Jones GP, Caley MJ (1999) Experimental evaluation of the roles of habitat selection and interspecific competition in determining patterns of host use by two anemonefishes. Mar Ecol Prog Ser 186:283-292

Editorial responsibility: Otto Kinne (Editor), Oldendorf/Luhe, Germany
Steele MA (1997) Population regulation by post-settlement mortality in two temperate reef fishes. Oecologia 112: $64-74$

Stobutzki IC, Bellwood DR (1997) Sustained swimming abilities of the late pelagic stages of coral reef fishes. Mar Ecol Prog Ser 149:39-41

Sweatman HPA (1985) The influence of adults of some coral reef fishes on larval recruitment. Ecol Monogr 55:469-485

Tolimieri N (1995) Effects of microhabitat characteristics on the settlement and recruitment of a coral reef fish at two spatial scales. Oecologia 102:52-63

Wellington GM (1992) Habitat selection and juvenile persistence control the distribution of two closely related Caribbean damselfishes. Oecologia 90:500-508

Williams DMcB (1980) Dynamics of the pomacentrid community on small patch reefs in One Tree lagoon (Great Barrier Reef). Bull Mar Sci 30:159-170

Williams DMcB, English S, Milicich MJ (1994) Annual recruitment surveys of coral reef fishes are good indicators of patterns of settlement. Bull Mar Sci 54:314-331

Zar JH (1996) Biostatistical analysis. 3rd edn. Prentice-Hall, New York

Submitted: April 16, 2000; Accepted: August 8, 2001

Proofs received from author(s): January 21, 2002 